\title{
Koroze kovových spojovacích prostředků ve dřevě modifikovaném silikony
}

\section{Corrosion of metal fasteners in the silicone modified wood}

\author{
Daňková J. ${ }^{1}$, Majstríková T. ${ }^{1}$, Mec P. ${ }^{1}$, Ščučka J. ${ }^{2}$, Martinec P. ${ }^{2}$ \\ ${ }^{1}$ Katedra stavebních hmot a diagnostiky staveb, VŠB - TU Ostrava \\ ${ }^{2}$ Oddělení laboratorního výzkumu geomateriálů, Ústav geoniky AV ČR, v.v.i, Ostrava \\ E-mail: jana.dankova@vsb.cz
}

Ochranné prostredky na drevo ve stavebnich konstrukcich mohou, za určitých podminek, akcelerovat korozi kovových spojovacích prostředkü. Fenomén koroze kovů v chemicky modifikovaném dřevě silikony je významným faktorem pro stanovení adekvátnich pravidel pro uplatněni těchto materiálů v rámci stavebni konstrukce. $V$ článku jsou prezentovány výsledky experimentálni studie vlivu dřeva modifikovaného komerčním prostředkem na bázi silikonů na vybrané kovy. Bylo testováno modifikované dřevo smrku ztepilého (Picea Abies L.), dubu (Quercus SPP.) a modřinu opadavého (Larix decidua Mill.) a komerčni stavební kovové hřebíky železné, měděné a železné pozinkované. Vzorky dřeva s aplikovanými kovy byly exponovány 6 týdnù v prostředí s teplotou $30^{\circ} \mathrm{C}$ a vzdušnou vlhkostí $100 \%$, kdy vlhkost dřeva se bližila bodu nasycení vláken. Po uplynuti doby expozice bylo provedeno vizuální hodnocení povrchu ze dřeva vyjmutých kovových hřebíků, a $u$ vybraných vzorkủ byly korozní produkty analyzovány metodou infračervené spektroskopie. Výsledky provedených experimentů a analýz ukazuji na zrejmou materiálovou kompatibilitu mezi modifikovaným dřevem smrku ztepilého (Picea Abies L.) a železnými spojovacimi prostředky $v$ prostředi s vysokou vzdušnou vlhkostí. Po uplynutí expoziční doby byla intenzita koroze povrchu železného stavebního hřebíku nižši ve dřevě modifikovaném, než ve dřvě bez modifikace.

\section{ÚVOD}

Charakter prostředí, zejména úroveň vlhkosti a prrítomnost vody v kapalné formě výrazně ovlivňuje životnost dřevěných konstrukcí. V současné době je životnost stavebních konstrukcí a jejich částí normalizována na základě návrhových pravidel, tzv. Eurokódů. V tomto dokumentu [1] jsou uvedeny nejnižší požadované úrovně životnosti staveb. Avšak dřevo je, za určitých podmínek, dobře a poměrně rychle degradovatelné biologickými a abiotickými činiteli [2]. Z výše uvedených důvodů jsou ve stavebních konstrukcích dřevěné prvky obvykle opatřeny ochranným nátěrem, nebo je jinak zajištěn
Under certain circumstances, timber protective coatings may accelerate corrosion of metallic fasteners. The phenomenon of metal corrosion in wood chemically modified with silicones is a crucial factor for definition of appropriate rules for application of these materials on timber. The study presents results of the impact of modified spruce (Picea Abies L.), oak (Quercus SPP.) and larch (Larix decidua Mill.) timber and standard steel, copper and galvanised steel nails. Samples of timber with driven nails were exposed to the environment of $30^{\circ} \mathrm{C}$ temperature and $100 \%$ atmospheric humidity for a period of 6 weeks, when humidity of wood approximated the point of fibre saturation. After the exposure, the surface of steel nails removed from the timber was visually evaluated; corrosion products from selected samples were analysed using infrared spectroscopy. Based on the analyses results, the hypothesis of material compatibility between modified spruce (Picea Abies L.) timber and steel fixtures in the environment with high atmospheric humidity was formulated. After the exposure period, the extent of the surface corrosion of steel nail was lower than in untreated reference timber (without the protective coating).

způsob ochrany dřeva ve stavbě. Většina v současnosti známých a používaných ochranných prostředků na dřevo ovlivňuje strukturu dřevěného materiálu, a tím i jeho mechanické vlastnosti [3]. V této souvislosti je aktuální otázka, jak může tato změna struktury ovlivnit materiálovou kompatibilitu $\mathrm{v}$ rámci celkového uspořádání stavební konstrukce, a to zejména v kritických detailech stavební konstrukce, jako jsou např́klad spoje. V historických stavbách byly spoje jednotlivých částí dřevěných konstrukcí realizovány tesařskými spoji, nebo dřevěnými kolíky, čímž byl fenomén materiálové nekompatibility spojů redukován. $\mathrm{V}$ současné době jsou běžně, resp. téměř výhradně, používány kovové spojovací prostředky, 
jako jsou: hřebíky, vruty, svorníky, kovové kroužky, styčníkové desky, atd. Tyto spojovací prostředky mohou být vyrobeny $\mathrm{z}$ různých kovových materiálů a mohou mít různou povrchovou úpravu. Kompatibilita kovových materiálů a ošetřeného dřeva je zcela zásadní z hlediska spolehlivosti stavebních konstrukcí, nebot' spoje ovlivňují statickou způsobilost celé stavby.

Dřevo a kovy jsou ve většině prípadů kompatibilní materiály v suchém prostředí. Přri zvýšené vlhkosti, nebo při nasycení dřeva vodou, probíhají korozní děje, kdy dřevo koroduje kov a kov koroduje dřevo. Přírodní extraktivní látky obsažené ve dřevě, nebo syntetické chemikálie obsažené $\mathrm{v}$ ochranných prostředcích na dřevo, se mohou účastnit korozních dějů. Mohou být akcelerátory nebo inhibitory těchto korozních dějů [4].

Předpokládá se, že koroze kovů ve dřevě je vodný proces, který se vyskytuje za př́tomnosti volné vody $\mathrm{v}$ buněčných stěnách a $\mathrm{v}$ lumenech buněk, při vyšším obsahu vlhkosti dřeva. Mechanismus vodné koroze je reálná skutečnost, protože korozívnost dřeva silně závisí na obsahu vlhkosti dřeva, přičemž je prahový obsah vlhkosti dřeva $15-18 \mathrm{hm}$. \%. Pod touto hodnotou se žádná koroze kovi̊ ve dřevě neuskutečňuje. Následuje oblast, kde se rychlost koroze zvyšuje s rostoucím obsahem vlhkosti, a poté úroveň, nad kterou je míra koroze konstantní s obsahem vlhkosti dřeva. Tyto tři fáze korespondují s fází adsorpce vody ve dřevě [5].

Některé dřeviny mají prrirozenou schopnost korodovat kovy, např. dřevo dubu Quercus SPP [6]. Obecně, čím má dřevo nižší $\mathrm{pH}$, tím je vyšší nebezpečí koroze kovů ve dřevě [7]. Dalšími faktory, které ovlivňují rychlost koroze a scénáře korozních dějů kovů ve dřevě jsou: množství kyslíku, vysoká vlhkost dřeva, zasolení, kvalita povrchu a čistota kovu ve dřevě, atd. [4]. Mezi prvními autory, kteří popsali degradační proces železných kovů v mokrém, neošetřeném dřevě byli Fontana a Green [8] a Pinion [9].

Ochranné prostředky na dřevo jsou běžně použivány od konce 19. století. Impulsem pro vývoj a výzkum ochranných prostředků na dřevo byla potřeba prodloužit životnost dřevěných konstrukcí nově vznikající infrastruktury, např. železničních pražců a mostů nebo telegrafních sloupů. Použití ochranných prostředků na dřevo ve stavebních konstrukcích je v současnosti normalizováno systémem technických norem [2].

Avšak problematika chemické ochrany dřeva je v současné době přehodnocována ve vztahu $\mathrm{k}$ vlivům na životní prostředí. Dřevo ošetřené prostředky s obsahem karcinogenních nebo jinak nebezpečných látek se stává, po ukončení životnosti konstrukce, nebezpečným odpadem. Výroba a distribuce takových ošetřujících prostředků má také významné dopady na životní prostředí. Je také známo, že některé ochranné prostředky dřevo poškozují [10]. Struktura takto chemicky ošetřeného dřeva se mění [11], přirozené stárnutí dřeva se mění na korozní děje s nestandartními projevy, dřevo má horší mechanické vlastnosti [12].
Koroze kovů ve dřevě ošetřeném kreosoty popsal Nelson [13]. Prostředky na olejové bázi málo, ale přece akcelerují korozní mechanismy kovů $\mathrm{v}$ ošetřeném dřevě. Anorganické fungicidy, např́íklad chróm-měd'-arsénové soli neakcelerují korozi kovů tak rapidně, jako jiné prostředky [14], které byly vyvinuty později, jako jejich náhrada. Je publikována řada výsledků výzkumných prací, zabývajících se vlivem ošetřujících prostředků na dřevo obsahující měd', na akceleraci koroze kovů v takto ošetřeném dřevě. Baker se domnívá, že se jedná o mechanismus galvanické koroze mezi měd'natými ionty $(\mathrm{Cu}++)$, které jsou obsaženy $\mathrm{v}$ ochranných prostředcích na dřevo a kovovými spojovacími prvky.

Avšak obecně lze konstatovat, že v současnosti neexistuje teorie, která by úplně a přesně vystihovala účinky syntetických chemikálií v ošetřeném dřevě na korozi kovů. Účinek chemikálií, obsažených v různých ošetřujících prostředcích na dřevo, ve vztahu ke koroznímu mechanismu tedy není úplně zřejmý [5].

Jestliže se toto tvrzení vztahuje k ochranným prostředkům, které jsou používány již delší dobu (20-50 let), pak o to více platí pro nové a nově vyvíjené materiály a technologie ochrany dřeva. Za novou technologii lze považovat také chemickou modifikaci dřeva silikony.

Je prokázáno [15], že dřevo ošetřené vybranými silikony vykazuje rozměrovou stabilitu vůči vlhkosti a povětrnostním podmínkám [16], biologickou odolnost [17,18], a má také lepší požární vlastnosti [19]. Dřevo ošetřené silikony je považováno za chemicky modifikované dřevo, nebot' je změněna jeho struktura také na molekulární strukturální hladině.

Modifikace dřeva silikony se $\mathrm{z}$ důvodů výše uvedených jeví jako perspektivní technologie ochrany dřevěných konstrukcí ve stavebnictví. Zejména $\mathrm{v}$ takovém prostředí, kde je uplatněna schopnost povrchu dřeva odpuzovat kapalnou vodu. Je však dosud málo publikovaných prací o problematice materiálové kompatibility $\mathrm{v}$ rámci stavebních konstrukcí z modifikovaného dřeva. Tento článek se zabývá vlivem modifikace dřeva silikony na kovové spojovací prostředky.

\section{EXPERIMENTÁLNÍ ČÁST}

Vzorky o rozměrech $50 \times 50 \times 60 \mathrm{~mm}(\mathrm{~T} \times \mathrm{L} \times \mathrm{R})$ byly připraveny ze dřeva dubu (Quercus SPP.), modřínu opadavého (Larix decidua Mill.) a smrku ztepilého (Picea abies L.) vyřezáním z profilů větších průřezů, u nichž bylo ošetření realizováno v roce 2013 (Tab. 1). Ošetření dřeva bylo máčením ve vodném roztoku LUKOFOBU 39 s hmotnostní koncentrací 50\%. LUKOFOB 39 je komerční produkt vyráběný $\mathrm{v}$ Lučebních závodech Kolín [20,21]. Tento organo-anorganický silanolátový produkt obsahuje $20 \%$ methylsilanolátu draselného $\left(\mathrm{CH}_{3} \mathrm{~K}_{3} \mathrm{O}_{3} \mathrm{Si}\right)$, a $19 \%$ jiných ve vodě nerozpustných složek. Složení kovů hřebíků viz Tab. 2. Chemické slo- 
žení kovů hřebíků bylo stanoveno přístrojem NITON XL3 (ruční rentgenový spektrometr). Cílem testování bylo identifikovat korozní produkty na povrchu kovi̊ a posoudit intenzitu koroze.

Tab. 1. Identifikace vzorků; ošetření dřeva / Identification of samples, treatment of wood

\begin{tabular}{|l|c|c|c|}
\hline \multirow{2}{*}{ Doba máčení } & \multicolumn{3}{|c|}{ Označení souboru vzorků } \\
\cline { 2 - 4 } & $\begin{array}{c}\text { Dub } \\
\text { (Quercus } \\
\text { SPP.) }\end{array}$ & $\begin{array}{c}\text { Modř́n } \\
\text { opadavý } \\
\text { (Larix } \\
\text { decidua } \\
\text { Mill.) }\end{array}$ & $\begin{array}{c}\text { Smrk } \\
\text { ztepilý } \\
\text { (Picea } \\
\text { abies } \text { L. })\end{array}$ \\
\hline 0 hodin - referenční & DR & MR & SR \\
\hline 4 hodiny & DA & MA & SA \\
\hline 8 hodin & DB & MB & SB \\
\hline 24 hodin - 1 den & DC & MC & SC \\
\hline 28 dnů & DG & MG & SG \\
\hline
\end{tabular}

Tab. 2. Identifikace vzorků; chemické složení kovů / Identification of samples, chemical composition of metals

\begin{tabular}{|c|c|}
\hline Hřebík & Složení \\
\hline $\mathrm{Fe}$ & $\begin{array}{c}0,483 \% \mathrm{Si}, 0,053 \% \mathrm{P}, 0,024 \% \mathrm{~S}, 0,025 \% \mathrm{Ti} \\
0,065 \% \mathrm{~V}, 0,078 \% \mathrm{Cr}, 1,15 \% \mathrm{Mn}, 97,38 \% \mathrm{Fe} \\
0,204 \% \mathrm{Ni}, 0,299 \% \mathrm{Cu}, 0,012 \% \mathrm{Mo}, 0,011 \% \mathrm{Sn}\end{array}$ \\
\hline $\mathrm{FeZn}$ & $\begin{array}{c}0,188 \% \mathrm{Si}, 0,166 \% \mathrm{Cr}, 0,111 \% \mathrm{Mn}, 25,49 \% \mathrm{Fe} \\
0,411 \% \mathrm{Co}, 0,062 \% \mathrm{Cu}, 73,49 \% \mathrm{Zn}, 0,015 \% \mathrm{Sn} \\
\text { Tloušt'ka vrstvy zinku } 10,2 \mu \mathrm{m}\end{array}$ \\
\hline $\mathrm{Cu}$ & $0,337 \% \mathrm{Si}, 0,029 \% \mathrm{~S}, 0,066 \% \mathrm{Fe}, 99,55 \% \mathrm{Cu}$ \\
\hline
\end{tabular}

Vzorky dřeva s aplikovanými kovovými stavebními hřebíky 3,1/80 ČSN 022810.1 [22] byly uloženy v prostředí $30^{\circ} \mathrm{C} / 100 \%$ R.V., po dobu 6 týdnů. Pouze část dříku hřebíku byla vpravena do dřeva. Každý hřebík byl tedy po délce dříku vystaven dvěma druhům prostředí. Prostředí vlhkého dřeva (vlhkost dřeva byla na úrovni blížící se bodu nasycení vláken) a prostředí, kdy byl kov zatížen pouze vlivem působení vlhkého vzduchu $30^{\circ} \mathrm{C} / 100 \%$ R.V. Po uplynutí doby expozice byly kovy ze dřeva vyjmuty, bylo provedeno vizuální hodnocení povrchu kovů (Tab. 3). U vybraných skupin vzorků byla provedena optická mikroskopie (Obr. 1, 2) a identifikace korozních produktů pomocí infračervené spektroskopie (dále jako FTIR analýza). Pro fotodokumentaci vzorků byl použit stereomikroskop NIKON SMZ 25, vybavený stacionární CCD kamerou NIKON DS-5M a digitální fotoaparát NIKON D700 s makroobjektivem.

Předběžná identifikace korozních produktů byla realizována na vzorcích SG-Fe, SR-Fe, SG-Cu a SR-Cu
Tab. 3. Vizuální hodnocení povrchu kovů / Visual evaluation of the surface of metals

\begin{tabular}{|c|c|c|}
\hline Vzorek & Kovy & $\begin{array}{l}\text { Vizuální hodnocení rozsahu koroze } \\
\text { na povrchu kovu* }\end{array}$ \\
\hline \multirow{3}{*}{ MR } & $\mathrm{MR}-\mathrm{Fe}$ & +++ \\
\hline & $\mathrm{MR}-\mathrm{Cu}$ & ++ \\
\hline & MR-FeZn & ++ \\
\hline \multirow{3}{*}{ DR } & $\mathrm{DR}-\mathrm{Fe}$ & +++ \\
\hline & $\mathrm{DR}-\mathrm{Cu}$ & ++ \\
\hline & DR-FeZn & 0 \\
\hline \multirow{3}{*}{ SR } & $\mathrm{SR}-\mathrm{Fe}$ & +++ \\
\hline & $\mathrm{SR}-\mathrm{Cu}$ & ++ \\
\hline & $\mathrm{SR}-\mathrm{FeZn}$ & + \\
\hline \multirow{3}{*}{ MA } & MA-Fe & +++ \\
\hline & $\mathrm{MA}-\mathrm{Cu}$ & ++ \\
\hline & MA-FeZn & 0 \\
\hline \multirow{3}{*}{ DA } & $\mathrm{DA}-\mathrm{Fe}$ & +++ \\
\hline & $\mathrm{DA}-\mathrm{Cu}$ & $0 \mathrm{až}+$ \\
\hline & DA-FeZn & 0 \\
\hline \multirow{3}{*}{ SA } & $\mathrm{SA}-\mathrm{Fe}$ & +++ \\
\hline & $\mathrm{SA}-\mathrm{Cu}$ & ++ \\
\hline & $\mathrm{SA}-\mathrm{FeZn}$ & 0 \\
\hline \multirow{3}{*}{ MB } & MB-Fe & +++ \\
\hline & $\mathrm{MB}-\mathrm{Cu}$ & 0 \\
\hline & MB-FeZn & ++ \\
\hline \multirow{3}{*}{ DB } & DB-Fe & ++ \\
\hline & $\mathrm{DB}-\mathrm{Cu}$ & 0 \\
\hline & DB-FeZn & + \\
\hline \multirow{3}{*}{ SB } & $\mathrm{SB}-\mathrm{Fe}$ & +++ \\
\hline & $\mathrm{SB}-\mathrm{Cu}$ & + \\
\hline & $\mathrm{SB}-\mathrm{FeZn}$ & ++ \\
\hline \multirow{3}{*}{$\mathrm{MC}$} & $\mathrm{MC}-\mathrm{Fe}$ & +++ \\
\hline & $\mathrm{MC}-\mathrm{Cu}$ & + \\
\hline & MC-FeZn & + \\
\hline \multirow{3}{*}{ DC } & $\mathrm{DC}-\mathrm{Fe}$ & +++ \\
\hline & $\mathrm{DC}-\mathrm{Cu}$ & +++ \\
\hline & DC-FeZn & +++ \\
\hline \multirow{3}{*}{$\mathrm{SC}$} & $\mathrm{SC}-\mathrm{Fe}$ & +++ \\
\hline & $\mathrm{SC}-\mathrm{Cu}$ & ++ \\
\hline & $\mathrm{SC}-\mathrm{FeZn}$ & ++ \\
\hline \multirow{3}{*}{ MG } & $\mathrm{MG}-\mathrm{Fe}$ & ++ \\
\hline & $\mathrm{MG}-\mathrm{Cu}$ & ++ \\
\hline & MG-FeZn & ++ \\
\hline \multirow{3}{*}{ DG } & DG-Fe & +++ \\
\hline & DG-Cu & +++ \\
\hline & DG-FeZn & ++ \\
\hline \multirow{3}{*}{ SG } & $\mathrm{SG}-\mathrm{Fe}$ & +++ \\
\hline & $\mathrm{SG}-\mathrm{Cu}$ & +++ \\
\hline & SG-FeZn & +++ \\
\hline
\end{tabular}

* 0 žádné viditelné znaky korozního napadení, + nepatrný výskyt korozního napadeni, ++ středni intenzita výskytu korozního napadeni, +++ vysoká intenzita výskytu korozního napadeni 
(Obr. 3-6) FTIR analýzou v rozsahu 400-4000 $\mathrm{cm}^{-1}$. $\mathrm{Na}$ vzorcích SG-Cu a SR-Cu byly také provedeny mikrochemické, kapkové testy (Cu, sírany).

\section{VÝSLEDKY}

Koroze kovových spojovacích prostředků je patrná u všech vzorků ve stavu referenčním, tzn. u neošetřeného dřeva. Prokazatelná koroze u kovů $\mathrm{Cu}, \mathrm{FeZn}, \mathrm{Fe}$ pro smrk na úrovni ošetření $\mathrm{B}, \mathrm{C}, \mathrm{G}$.

Jako nestandartní se jeví průběh koroze kovů v ošetřeném dřevě modřínu opadavého (Larix decidua Mill.). Na základě vizuálního a mikroskopického hodnocení povrchu kovů lze vyslovit domněnku, že součástí korozního povlaku je pryskyrrice (ronění pryskyřrice bylo zřejmé po dobu exponování), nebo nějaký, dosud blíže nespecifikovaný, korozní produkt reaktantu extraktivní látky modřínového dřeva. Interpretace korozních procesů pro kovy $\mathrm{v}$ ošetřeném dřevě modřínu opadavého bude vyžadovat podrobnější analýzy.

U dřeva dubu bude korozní proces pravděpodobně zcela odlišný, než u jehličnatých dřevin modřínu opadavého (Larix decidua Mill.) a smrku ztepilého (Picea abies L.). Avšak z hlediska praktického využití, dub pro svou prrirozenou trvanlivost 2 až 2-3 dle [23] není dřevinou typickou pro realizaci chemické modifikace.

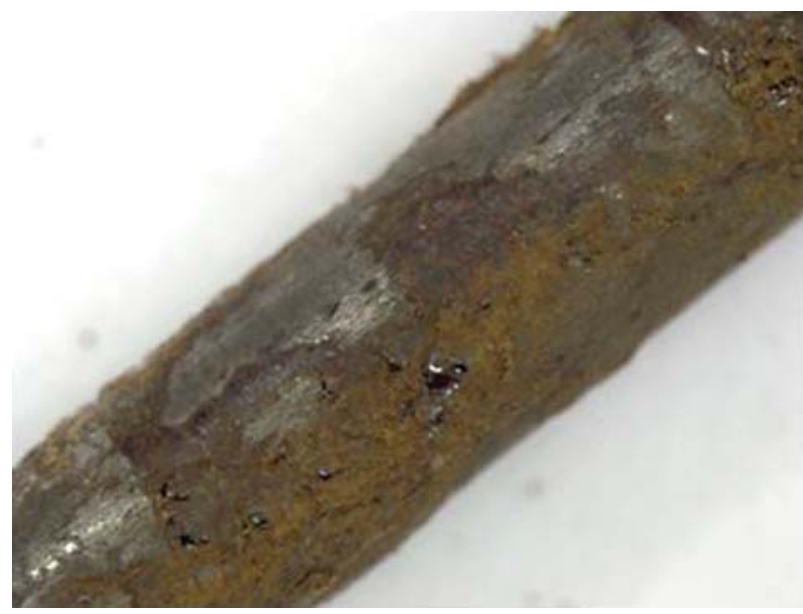

a)

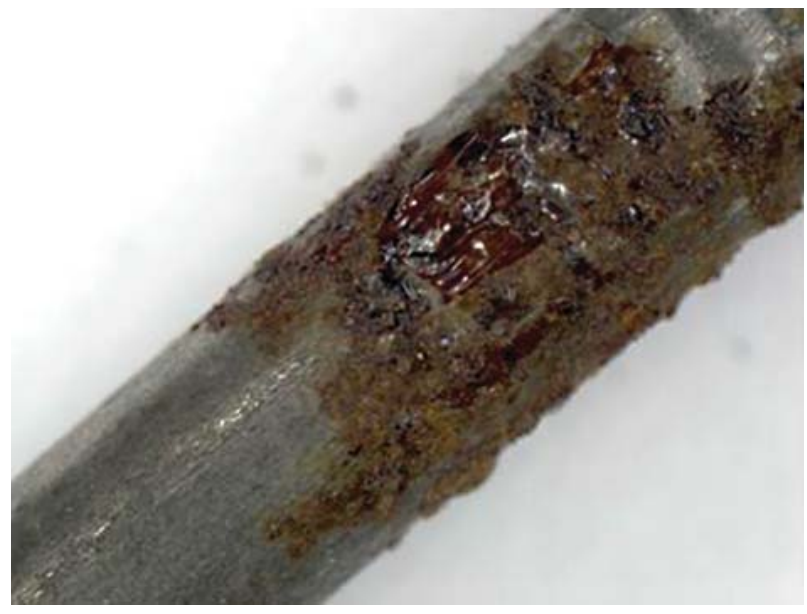

b)

Obr. 1. Identifikace povrchu železného hřebíku (Fe) ve dřevě SG (smrku ztepilého Picea abies L. ošetřeného máčením po dobu 28 dnů

Fig. 1. Identification of the surface of the iron nail (Fe) in the wood SG - Norway spruce (Picea abies L.) treated by dipping for 28 days

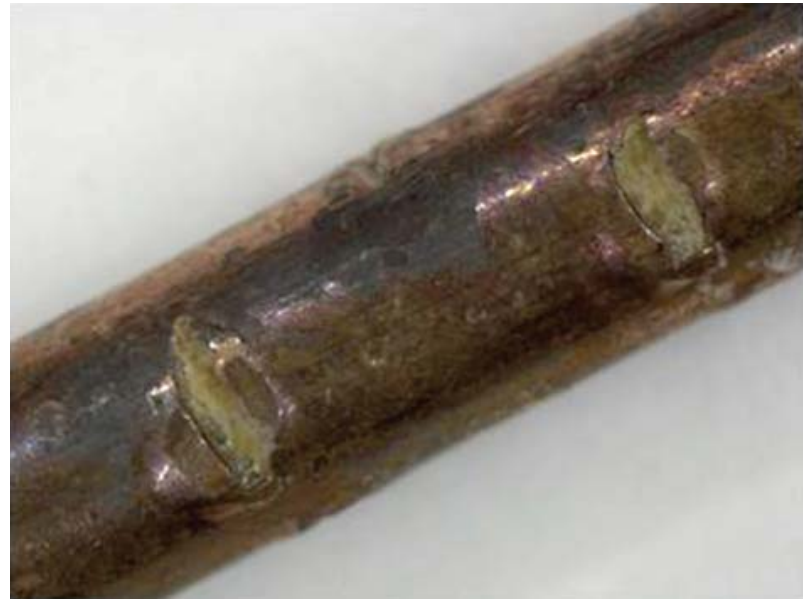

a)

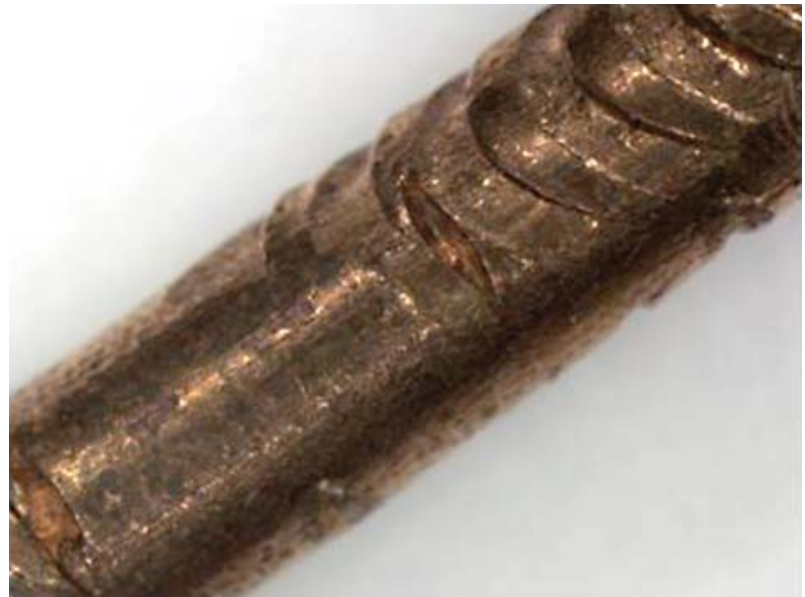

b)

Obr. 2. Identifikace povrchu měděného hřebíku $(\mathrm{Cu})$ ve dřevě SG (smrku ztepilého Picea abies L. ošetřeného máčením po dobu 28 dnů

Fig. 2. Identification of the surface of the copper nail (Cu) in the wood SG - Norway spruce (Picea abies L.) treated by dipping for 28 days 
Z hlediska praktického využití je nejzajímavější chování kovů v modifikovaném dřevě smrku ztepilého (Picea abies L.).

Obě spektra $($ Obr. 3,4$)$ vzorků SR-Fe a SG-Fe jsou velmi blízká, téměř shodná. Na pozadí spektra smrkového dřeva (převaha celulózy nad hemicelulózami a ligninem) jsou absorpční pásy náležející bezpečně nanočásticím goethitu. Obsah goethitu je mírně vyšší ve vzorku SR-Fe. Z tvaru absorpčních pásů je zřejmé, že spolu s goethitem se vyskytují velmi jemné, až amorfní částice nespecifikovaného Fe-oxohydritu. Sírany v obou vzorcích, SR-Fe a SG-Fe, nebyly mikrochemicky prokázány.
Obě spektra (Obr. 5, 6) SG-Cu a SR-Cu jsou velmi blízká, téměř shodná. Na pozadí spektra smrkového dřeva (převaha celulózy nad hemicelulózou a ligninem) jsou absorpční pásy náležející bezpečně nanočásticím, přechodným nestechiometrickým sloučeninám, $\mathrm{v}$ řadě malachit $\mathrm{Cu}_{2}(\mathrm{OH})_{3}\left[\mathrm{CO}_{3}\right]$, azurit $\mathrm{Cu}_{3} \mathrm{OH}\left[\mathrm{CO}_{3}\right]_{2}$. Jedná se o částice, velmi jemnozrnné, které jsou navíc vázány na celulózovou fázi. Mikrochemicky byla určena elementární $\mathrm{Cu}$ (amoniakem), mikrochemicky nebyly prokázány $\left(\mathrm{BaCl}_{2}\right)$ sírany. Na vzorku $\mathrm{SG}-\mathrm{Cu}$ je patrně vyšší zastoupení korozních produktů než SR-Cu.

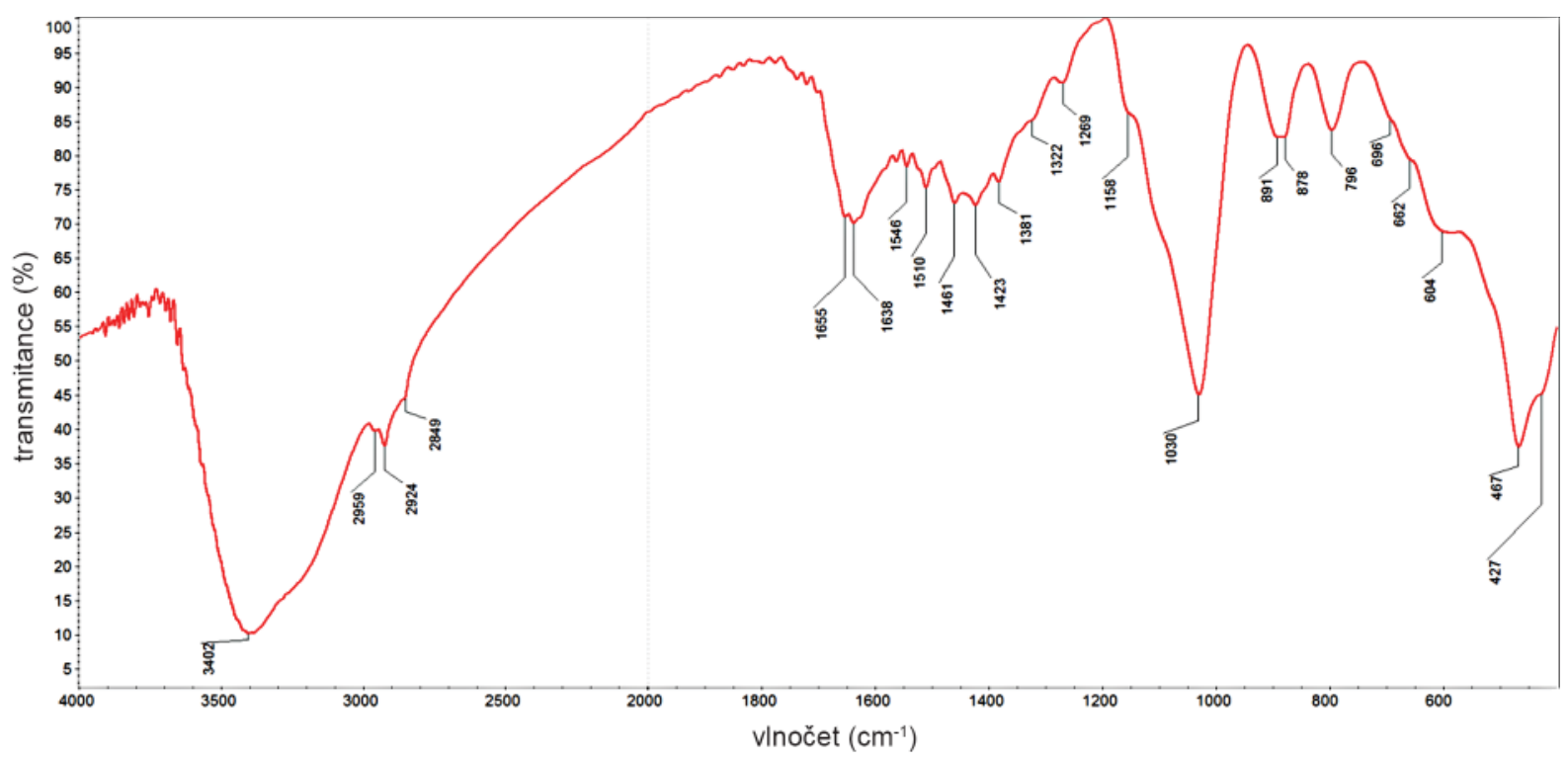

Obr. 3. Výsledek FTIR analýzy vzorku SG-Fe

Fig. 3. The FTIR analysis results for the sample SG-Fe

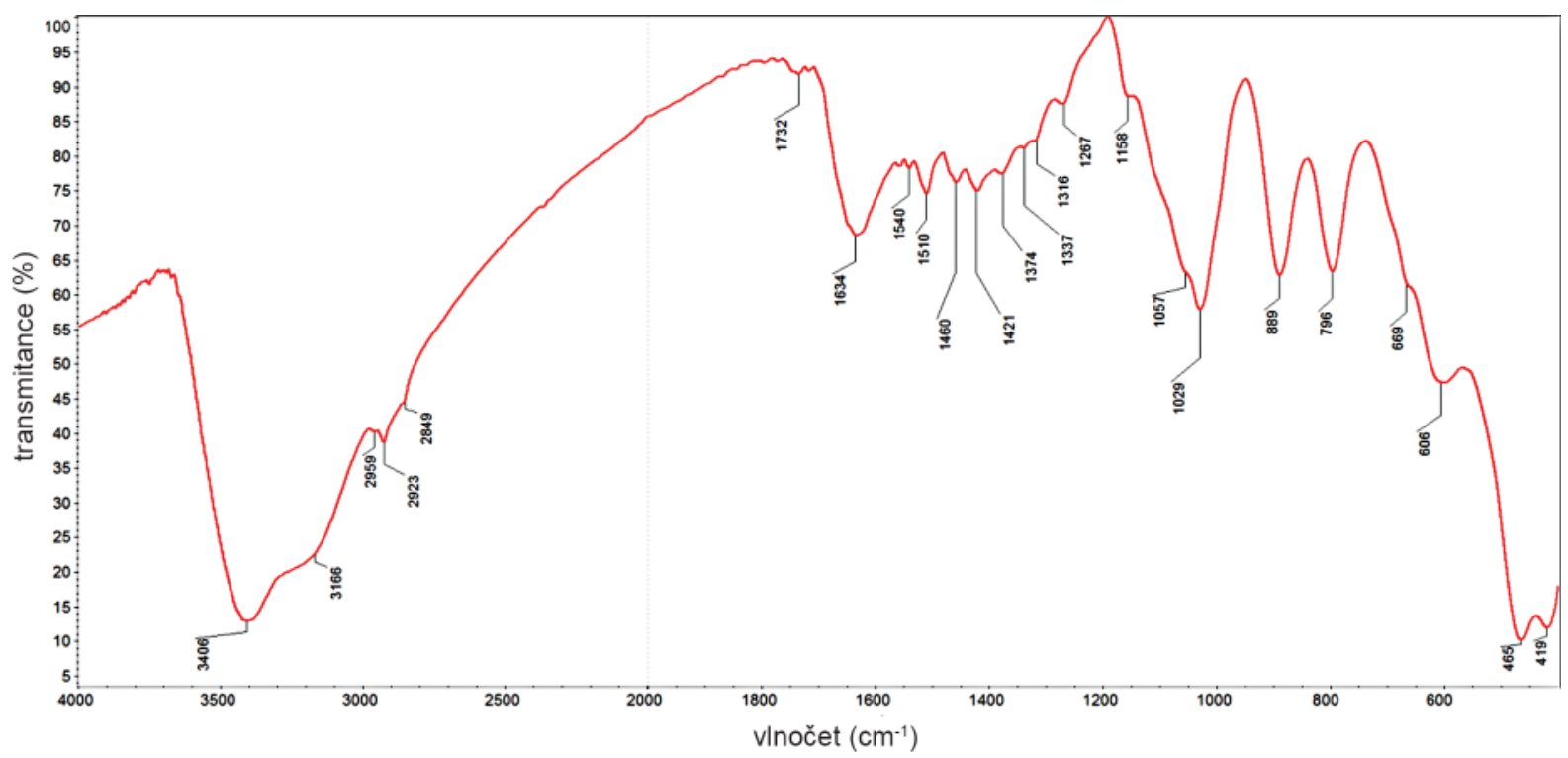

Obr. 4. Výsledek FTIR analýzy vzorku SR-Fe

Fig. 4. The FTIR analysis results for the sample SR-Fe 




Obr. 5. Výsledek FTIR analýzy vzorku SG-Cu

Fig. 5. The FTIR analysis results for the sample SG-Cu

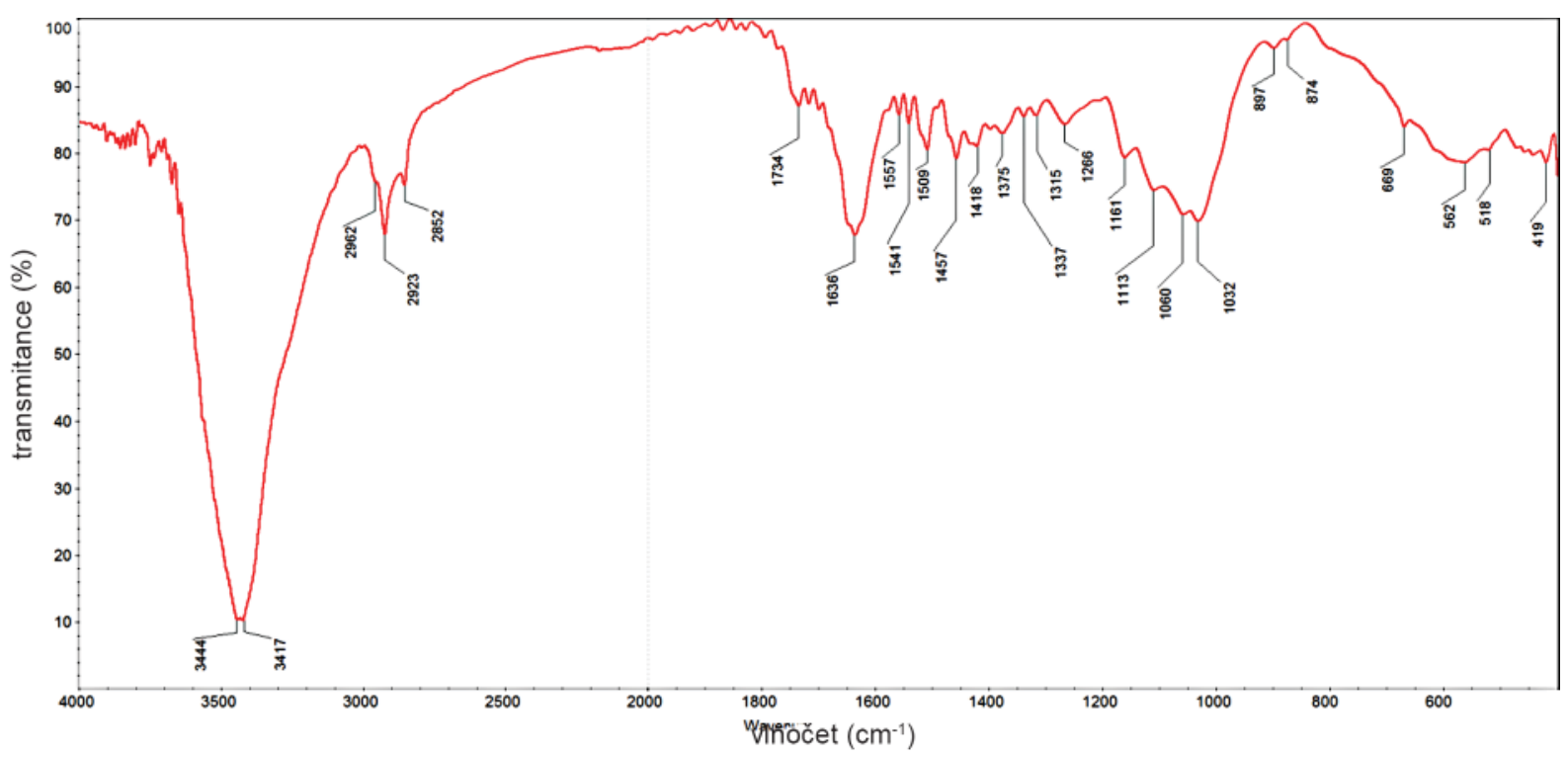

Obr. 6. Výsledek FTIR analýzy vzorku SR-Cu

Fig. 6. The FTIR analysis results for the sample SR-Cu

\section{DISKUZE A ZÁVĚR}

Z výsledků realizovaných experimentů lze předpokládat, že chemicky modifikované dřevo smrku ztepilého (Picea abies L.) prostředkem LUKOFOB 39 a železné spojovací prostředky (hřebíky) budou vykazovat uspokojivou materiálovou kompatibilitu v prostředí stavební konstrukce vystavené vyšší vzdušné vlhkosti. $Z$ realizovaných experimentů však není zřejmé, jak se bude korozní proces vyvíjet $\mathrm{z}$ hlediska dlouhodobé expozice, $v$ rrádu měsíců a roků. Další výzkum bude směřovat ke kvantifikaci korozních produktů, $\mathrm{k}$ vyšetření rychlosti korozního procesu a ostatních chemicko-fyzikálních veličin, které definují korozní procesy kovů $\mathrm{v}$ elektrolytech.

\section{Poděkování}

Práce byly podporovány z prostředkủ koncepčního rozvoje vědy, výzkumu a inovací pro rok 2015 pridèlených VŠB-TUO Ministerstvem školství, mládeže a tělovýchovy $\check{C} R$. 


\section{LITERAURA}

1. ČSN EN 1990. Eurokód: Zásady navrhování konstrukcí. Praha: ČSNI, 2011. 76 p.

2. Reinprecht, L. Ochrana dreva, 1.st ed.; TU vo Zvolene: Zvolen, 2008.

3. Yildiz, U. C., Temiz, A., Gezer, E. D., \&Yildiz, S. Effects of the wood preservatives on mechanical properties of yellow pine (Pinus sylvestris L.) wood. Building and Environment. 2004, 39(9), 1071-1075.

4. Graham, R. and Oteng - Amoako, A. Wood-metal corrosion: an annotated survey. Technical Report, Oregon State University. Forest Research Laboratory, 1976.

5. Zelinka, S.L., and Douglas, R. R. Review of test methods used to determine the corrosion rate of metals in contact with treated wood; WI: US Department of Agriculture, Forest Service, Forest Products Laboratory: Madison, 2005.

6. Kopecká, I., Dvořák, M. Nároky na muzejní úložné prostory z hlediska stability různých materiálů. Př́loha časopisu Zprávy památkové péče. 1995, 55 (8), I-XIV.

7. Corrosion of Metals by wood.http://www.npl.co.uk. upload/ pdf/corrosion_of_metals_by_wood.pdf (accessed Sept 15, 2015).

8. Fontana, M.G.; Greene, N.D. Corrosion Engineering; Mc Graw-Hill: New York, 1967.

9. Pinion, L. C. The degradation of wood by metal fastenings and fittings. 1970.

10. Kučerová I., et al. Koroze dřeva ochrannými přípravky na bázi anorganických sloučenin, Koroze a ochrana materiálu 2010, 54(4), 138-147.

11. Antušková, V., Kučerová, I. The impact of inorganic compounds used for protection of wood on cellulose. Koroze a ochrana materialu 2014, 58(2), 36-42.
12. Effects of waterborne preservative treatment on mechanical properties: a review., $91^{\text {st }}$ annual meeting of American Wood Preservers' Association; Winandy, J. E., Ed.; 1995.

13. Nelson, G. Corrosion Data Survey, 1967 edition; National Association of Corrosion Engineers: Houston, 1968.

14. Baker, A.J. Corrosion of nails in CCA-and ACA-treated. Forest Products Journal, 1992, 42(9), 39.

15. Reinprecht, L., et al. Performance of methyl-tripotassiumsilanol treated wood against swelling in water, decayfungi and moulds. Wood Research, 2013, 58.4: 511-520.

16. Donath, S., et al. Weatheringof silane treated wood. Holz als Roh-und werkstoff, 2007, 65 (1), 35-42.

17. De Vetter, L., et al. Fungal decay resistance and durability of organosilicon-treated wood. International Biodeterioration \& Biodegradation, 2009, 63, 130-134.

18. Terziev, N., Temiz, A. Wood Modification: Processes, Properties a Commercialisation. In Chemical modification of wood with silicon compounds, $2^{\text {nd }}$ European Conference on Wood Modification, Gottingen (Germany); 2005; pp 242-245.

19. Saka, S., Ueno, T. Several $\mathrm{SiO}_{2}$ wood-inorganic composites and their fire-resisting properties. Wood science and technology, 1997, 31(6), 457-466.

20. http://www.lucebni.cz/data/File/lukofob-napostedlo/ Bezpecnostni\%20listy/Lukofob\%2039.pdf (accessed Sept 15, 2015).

21. http://www.lucebni.cz/data/File/lukofob-napostedlo/ Prospekty/Lukofob.pdf (accessed Sept 15, 2015).

22. ČSN 022810 Stavebné klince s plochou hlavou. Praha: ČSNI, 1970. 2p.

23. ČSN EN 350-2 Trvanlivost dřeva a materiálů na jeho bázi - Přirozená trvanlivost rostlého dřeva - Část 2: Přirozená trvanlivost a impregnovatelnost vybraných dřevin důležitých v Evropě. Praha: ČNI, 1996. 34p. 